\title{
An Appraisal of the Activities of Central Depository Bangladesh Limited (CDBL)
}

\author{
Tanbir Ahmed Chowdhury ${ }^{1} \&$ Farzana Huda $^{2}$ \\ ${ }^{1}$ Faculty of Business and Economics, East West University, Dhaka, Bangladesh \\ ${ }^{2}$ Department of Business Administration, East West University, Dhaka, Bangladesh \\ Correspondence: Tanbir Ahmed Chowdhury, Professor Dr., Dean, Faculty of Business and Economics, East West \\ University, A/2 Jahirul Islam City, Aftabnagar, Dhaka 1212, Bangladesh. E-mail: tanbir@mail.ewubd.edu
}

Received: October 18, 2016

Accepted: November 9, 2016

Online Published: December 18, 2016

doi:10.5539/ijef.v9n1p169

URL: http://dx.doi.org/10.5539/ijef.v9n1p169

\begin{abstract}
In Bangladesh the establishment of Central Depository Bangladesh Limited (CDBL) added value to the stock market and plays a vital role in the progress of economic development. CDBL is engaged in the operations of the Central Depository System (CDS), a major financial market infrastructure in Bangladesh established as a part of the overall financial sector development. This study tried to analyze the growth and development of CDBL. Seven trend equations have been tested for different activities of CDBL.It is observed that CDBL was able to achieve a stable growth of listed securities in CDS, depository participants, settlement of securities transactions, documentation of CDBL, total assets and net income during the period of 2007-2015. Square of correlation coefficient $\left(\mathrm{r}^{2}\right)$ has also been tested for all trend equations. It indicates the prospect of CDBL in Bangladesh is relatively bright.
\end{abstract}

Keywords: central depository system, dematerialization, rematerilisation, earnings per share, net income

\section{Introduction}

In the developing economy firms and enterprises raised their capital by selling their common stock to expand business through capital market. The pattern of corporate finance in Bangladesh has undergone transformation at different times. Before liberation in 1971 the managing agency system provided the nucleus of finance for the corporate sector due to shyness of investor, imperfect capital market and lack of strong networks of financial system. After independence, Bangladesh witnessed drastic changes in the financial structure, particularly in view of the shift in Government policy toward socialistic approach of development. In consistent with the broader national objectives the abolition of managing agency system, suspension of stock exchange activities, nationalization of all banks, insurance companies and major industries, reorientation of credit and industrial policy took place. In 1975, a policy shift was adopted with the change of Government emphasizing private sectors. This shift in reliance from public to private sectors resulted reactivating Dhaka Stock Exchange in 1976. The only bourse of the country at that time and setting up of Investment Corporation of Bangladesh (ICB) intended to facilitate development of stock market. The second stock exchange of the country, Chittagong Stock exchange, was established on December, 1995 in Chittagong.

Early 1990s stock market in Bangladesh pretense a turmoil which creates the inevitability of Central Depository System (CDS), an electronic book entry system for custody and transfer of securities. CDS was introduced to replace the manual system of physical handling and settlement of shares at the stock exchange. This study will provide a pragmatic scenario of CDS from its inception to till date by breakdown of its escalation in terms of purpose, cost to revenue outline, contribution to the capital market, favorable to the participants and as a whole the economic development of Bangladesh.

\section{Literature Review}

Ali et al. (2011) examined the stock markets role in the capital formation in Pakistan from the period 1st January 2001 to 31st December 2008. The stock market size of capital, number of listed companies and liquidity positions has been examined in the study. The study revealed that Karachi Stock exchange is the oldest and biggest Stock exchange of Pakistan and it is the first mover to adapt institutional developments, new policies and procedures in the business of securities exchange and shares a big role in the capital formation in Pakistan. In 
recent years all stock exchanges have implemented the advanced technology and fully automated trading systems. This has changed the stock markets role in the capital formation as great boom has been observed during the study period.

Schmiedel (2006) investigated the existence and extent of economies of scale in depository and settlement system from 16 settlement institutions across different regions for the years 1993-2000 indicates the existence of significant economies of scale. The degree of such economies differs by size of settlement institution and region. While smaller settlement service providers reveal a high potential of economies for scale, larger institutions show an increasing trend toward cost effectiveness. Clearing and settlement systems in countries in Europe and Asia report substantially larger economies of scale than those of the US system. European cross-border settlement seems to be more cost intensive than that on a domestic level, reflecting chiefly complexities of EU international securities settlement systems and differences in the scope of international settlement service providers. The evidence also revealed that investments in implementing new systems and upgrades of settlement technology continuously improved cost effectiveness over the sample period.

According to Kamal (2006) investors should determine the cutoff point in between risk and return. The study tried to find out the impact of Central Depository System (CDS) listing, which is a new concept for shares instead of money. It holds securities of investors in electronic form. The very operation of CDS begins from the opening of a BO account can be opened with any participant of CDBL. The study also analyzed the operation of CDBL and its affects toward investors, issuers and brokers.

Corrado et al. (2000) examined that Central Depository System affects investors, insurers and brokers to a large extent. Investors are able to hold their securities in dematerialized form in a CDBL account; this removes the problems associated with physical certificates. Investors must have dematerialized Securities in their account before they instruct a stock broker to sell off. Securities resulting from a stock exchange bought trade will automatically be added to the investors account. Investors may rematerialize their securities or they may instruct with another participant or to a direct depository account. Securities in the account may be pledged to a bank or other financial institution without the need to withdraw them from the depository system. Investors, who have accounts in their own name, may request CDBL to issue them with a statement (to confirm the information given to them by their participant).

Hurkat and Ved (1999) discussed the role of depository system in many advanced countries in the stock and capital markets the world over. They also analyzed the services offered by depository system, dematerialization, re-materialization, trading and fee or charges, comparison of a bank and a depository for the benefits of the depository.

Shah (1996) highlighted that resolution of the single vs. multiple depositories, immobilization vs. dematerialization and role of capital adequacy norms for the custodians which really helpful in quick implementation of depository system in India.

Aggarwal and Dixit (1996) indicated the legal framework for depository system in India like benefits of the paperless trading, responsibilities of depository or participants and eligibility criteria, etc.

Sarkar (1996) analyzed the implications of the scrip less trading and share transfer based on book entry merely due to the existence of the depository ordinance 1995.

Gurusamy (1996) explained that the introduction of depository system would help in transfer of securities in the capital market by a mere book entry. He also pointed out the advantages of depository system such as delay in transfer, registration, fake certificates, soaring cost of transactions, more paper work, non availability of depositories in when the transfer of securities take place by physical delivery.

\section{Objectives of the Study}

The overall objectives of the study are:

- To present an overview of Central Depository system around the world.

- To appraise the activities of CDBL.

- To appraise the performance of CDBL.

- To identify the problems of CDBL.

- To suggest remedial measures for the development of CDBL.

\section{Scope and Methodology of the Study}

Both quantitative and qualitative analysis has been done in this study. All the information has been collected 
from secondary sources like published information, annual report, brochures, magazines and various articles. The study tried to analyze the performance and activities of CDBL from year 2007 to 2015 through the various statistical measures like growth percentage, trend equation, square of correlation coefficient etc.

\section{Central Depository System- Around the world}

Stock market is one of the most important financial institutions of any economy. Hafer and Hein (2007) notified that growth of new businesses or economy would not be possible without availability of stocks and development of financial markets and institutions like central depository system can ensure in the development of investors' confidence in the markets. There are now 62 approved central securities depositories all over the world.

\subsection{Japan Securities Depository Center, Inc. (JASDEC)}

JASDEC is a central securities depository in Japan designated under the Act on Transfer of Bonds, Shares, etc. JASDEC was established as a not-for-profit foundation in 1984 and incorporated as a stock company in 2002. In 2009, JASDEC accomplished dematerialization of stock certificates issued by all listed companies. With this step, new Book-entry Transfer System for stocks, corporate bonds and other securities has been fully established. JASDEC also provides pre-settlement matching system. JASDEC DVP Clearing Corporation, wholly owned by JASDEC, operates DVP settlement system for non-exchange transaction deliveries. As of the end of FY 2011 (March 2012), JASDEC's account balance of all the securities valued at JPY 696 trillion (US\$8.7 trillion). In FY 2011, JASDEC settled 83 millions of cases in securities transactions.

\subsection{Hong Kong Securities Clearing Company Limited (HKSCC)}

Hong Kong Securities Clearing Company Limited was incorporated in 1989 and launched the central clearing and settlement system (CCASS) in 1992 based on the immobilisation of share certificates in a central depository operated by HKSCC. Physical certificates deposited into CCASS become immobilized and are transformed into electronic records to effect settlement. All stock held in the CCASS Depository are fungible and not earmarked for a particular or transaction. CCASS depository offers physical shares deposit for settlement or for custodial safekeeping purpose as well as physical share withdrawal services to Direct Clearing Participants, General Clearing Participant, Custodian Participants as well as Investor Participants and Stock Pledge Participants. CCASS participants are responsible to HKSCC for the good title of the securities deposited into CCASS.

\subsection{Bursa Malaysia Depository Sdn. Bhd.}

Bursa Malaysia Depository Sdn. Bhd. is a wholly-owned subsidiary of Bursa Malaysia Berhad was established in April 1990 with a paid up capital of RM25 million and commenced operations in November 1992. It is the sole central depository for the Malaysian securities market, providing depository services for Exchange Traded Funds (ETF), equities and fixed income securities listed on the stock exchange. Bursa Malaysia has focused on various initiatives aimed at improving its product and service offerings, increasing the liquidity and velocity of its markets, improving the efficiency of its businesses and achieving economies of scale in its operations. On 18 March 2005, Bursa Malaysia was listed on the Main Board of Bursa Malaysia Securities Berhad with a 17\% or RM0.50 premium over its retail price of RM3.00.

\subsection{Thailand Securities Depository Co., Ltd. (TSD)}

Thailand Securities Depository Co., Ltd. (TSD) is a subsidiary of the Stock Exchange of Thailand was established on November 16, 1994 with a registered capital of THB 200 million, and commenced operations on January 1, 1995. TSD is the sole Central Securities Depository (CSD) in Thailand using scrip less system. The services provided by TSD are securities deposit, withdrawal, transfer, pledge and revocation. Investors can conduct the transactions through depository participants. TSD is also responsible for managing the foreign holding proportion of the securities traded on the main board and foreign board of the Stock Exchange of Thailand to comply with related rules and regulations.

\subsection{National Securities Depository Limited (NSDL)}

India had a vibrant capital market which is more than a century old, the paper-based settlement of trades caused substantial problems like bad delivery and delayed transfer of title till recently. The enactment of Depositories Act in August 1996 paved the way for establishment of NSDL, the first depository in India. NSDL, the first and largest depository in India, established in August 1996 and promoted by institutions of national stature responsible for economic development of the country has since established a national infrastructure of international standards that handles most of the securities held and settled in dematerialised form in the Indian capital market.

Using innovative and flexible technology systems, NSDL works to support the investors and brokers in the 
capital market of the country. NSDL aims at ensuring the safety and soundness of Indian marketplaces by developing settlement solutions that increase efficiency, minimise risk and reduce costs. NSDL play a central role in developing products and services that will continue to nurture the growing needs of the financial services industry.

\subsection{PT Kustodian Sentral Efek Indonesia (KSEI)}

PT Kustodian Sentral Efek Indonesia (KSEI - Indonesian Central Securities Depository), is the Securities Depository and Settlement Institution in the Indonesian capital market. KSEI was established on December 23, 1997 in Jakarta and obtained its operational license on November 11, 1998. Within the structure of the Indonesian capital market, KSEI is one of the few Self Regulatory Organizations (SROs), which includes PT Bursa Efek Indonesia (BEI) and PT Kliring Penjaminan Efek Indonesia (KPEI). In regards to the capital market, under the provisions of Law number 8 Year 1995, KSEI takes its role as LPP in the Indonesian capital market by providing orderly, fair, and efficient central Securities depository and transaction settlement services.

KSEI started its operational activities which handles Securities settlements in script form. On January 9, 1998 KSEI took over a similar function from PT Kliring Deposit Efek Indonesia (KDEI), which were once the Clearing Depository and Settlement Institution (LKPP). Afterwards, on July 17, 2000, KSEI together with BEI and KPEI made a breakthrough by implementing scrip less trading and central depository activities in the Indonesian capital market. KSEI shares are owned by its service users, namely: the SROs (IDX and KPEI), Custodian Banks, Securities Companies, and Registrars.

\subsection{Singapore Exchange Limited (SGX)}

SGX was formed on 1 December 1999 as a holding company and as of 31 January 2010, SGX had 774 listed companies with a combined market capitalisation of $\$ \$ 650$ billion. The revenues of SGX are mainly from the securities market (75\%) and derivatives market (25\%). SGX reported a net profit of $\$ 165.8$ million for the first half of its financial year 2010 .

\subsection{China Securities Depository and Clearing Corporation Limited (SD\&C)}

China Securities Depository and Clearing Corporation Limited (SD\&C) was established in accordance with the Securities Law of the People's Republic of China and the Company Law of the People's Republic of China. The total registered capital is RMB1.2billion which is being the largest operations of this type in the world. Shanghai Stock Exchange and Shenzhen Stock Exchange are shareholders of SD\&C, each holding 50\% equities. SD\&C was founded on 30 March, 2001 in line with related requirements by the Securities Law on establishing centralized securities registration and settlement operation.

In September 2001, SD\&C Shanghai branch and Shenzhen Branch were established. As of 1 October 2001, the SD\&C undertook all the securities registration and settlement business that used to be handled by Shanghai and Shenzhen Stock Exchanges, which marked the establishment of a centralized national securities registration and settlement framework. The mission of the SD\&C is to build an open, flexible and unified securities registration, clearing and settlement system in line with international standards and practices, better serving market players and supporting the development of China's securities market by improving market efficiency and effectively managing risks.

\section{Central Depository System in Bangladesh}

Early 1990s all securities are held in physical form which is called script based system i.e physical movement of securities certificates along with transfer deeds and registration with the company. Script based system of securities transactions involves enormous paper work involving certificates and deeds. It is also time consuming, bad deliveries due to signature difference, mistakes in completion of transfer of deeds, tearing and mutilation of certificates, fake certificates, and cost of transfer: stamp duty, postal delays and charges etc.

To lessen the obscurity of script base system and to make the capital market vibrant, depository system has been initiated which assist listed companies in the handling of script less transfer of ownership of shares, debentures, mutual funds and also government bonds and treasury bills in the electronic form .

The Depositories Act, 1999 provides a legal basis for the regulation of depositories in Bangladesh. It gives regulatory responsibility to the Securities and Exchange Commission (SEC) and enables the commission to make regulations concerning the operation of the depository. The Commission has published the Depository Regulations, 2000 which set out the criteria for companies that wish to establish depository systems. The Commission has also published the Depository (User) Regulations, 2003 which are concerned with the organizations that may become participants of the depository. CDBL has been granted a Certificate of Business 
Commencement from the Securities and Exchange Commission to begin operations. The CDBL By-laws define the acts and responsibilities of the CDBL, Depository Participants and Issuers.

CDBL was incorporated on 20th August 2000 in Bangladesh as a public limited company for running a central depository operation in Bangladesh. The Company is sponsored by the country's Nationalized Commercial Banks (NCBs), Investment Corporation of Bangladesh (ICB), Private Commercial Banks (PCBs), Foreign Banks, Merchant Banks, Publicly listed Companies, Insurance Companies and Dhaka \& Chittagong Stock Exchanges with the collaboration of the Asian Development Bank (ADB). The Company received registration from the Securities \& Exchange Commission (SEC) on 11th September 2001 under Depositories Regulations 2000 and subsequently obtained business commencement certificate on 23rd December 2003 from the SEC.

\section{Legal \& Regulatory Structure}

The Depositories Act, 1999 provides a legal basis for the regulation of depositories in Bangladesh. It gives regulatory responsibility to the Securities and Exchange Commission and enables the commission to make regulations concerning the operation of the depository. The Commission has published the Depository Regulations, 2000 which set out the criteria for companies that wish to establish depository systems. The Commission has also published the Depository (User) Regulations, 2003 which are concerned with the organizations that may become participants of the depository. CDBL has been granted a Certificate of Business Commencement from the Securities and Exchange Commission to begin operations. The CDBL Bye Laws, defines the acts and responsibilities of the CDBL, Depository Participants, and Issuers. CDBL is regulated by the Securities and Exchange Commission (SEC).

\section{Products \& Services of CDBL}

\subsection{Dematerialization}

Dematerialization is a process by which physical certificates are converted into electronic form for credit to the investors account in the depository. Once a security is eligible for holding in CDBL then all stock exchange trades must be settled through the depository. This means that sellers must have securities in the depository (i.e. the securities must have been dematerialized) before the broker can execute the sale order. To dematerialize securities investors should take their share certificates to a participant. The participant will request the investor to complete a dematerialization request form. The participant will take the documents to the issuer who (if the certificate is valid) will update the register by moving the securities from the certificated portion of the register to the depository portion. The issuer will then confirm the dematerialization to the depository and the depository will credit the securities to the investor's account. The participant will be able to see the balances in all the accounts that he controls through a computer link with CDBL. Investors do not need to wait until they wish to sell to dematerialize their holdings. Once a security is eligible, investors may open accounts and lodge securities at any time.

\subsection{Direct Accounts}

CDBL is offering a service to investors who wish to hold their securities in dematerialized form but do not wish to use a stockbroker or a bank to do so. Investors will be asked, by CDBL, to complete an account opening form. They will then be able to dematerialize existing holdings by giving the certificates to CDBL or to their stockbrokers and completing the dematerialization request form. When they wish to sell their securities they should instruct CDBL in writing to transfer the required number of securities to the stockbroker. When they buy they should instruct their stockbroker to transfer the securities to the Director Account on the settlement day. It is not necessary, in this case, to instruct CDBL. CDBL will not handle funds and investors must make arrangements to settle payments directly with their stockbrokers. CDBL will issue statements directly to the account holder on a monthly basis, if there are any movements and on a quarterly basis, if there are no movements.

\subsection{Rematerialisation}

To rematerialise securities that are in a CDBL account the account holder must instruct the participant through which he holds his account by completing a rematerialisation request form. The participant will instruct CDBL and the securities will then be debited from the account upon confirmation by the issuer. The issuer will transfer the holding from the depository portion of its register to the certificated portion of its register. The issuer will provide the investor with a share certificate within 30 days of a rematerialisation request.

\subsection{Buying and Selling}

The introduction of CDBL does not make any difference to the process of buying and selling although it does 
make a difference to the settlement of such trades. Where investors have a CDBL account through their broker then the act of giving a sell order to the broker also authorizes him to move Sucrets from the account to settle the sale. The broker will move the securities when he enters the order into the market. If the order is executed then the securities are used to settle the sale. If the order is not executed then the broker will move the securities back to the investor's account. Where investors have a CDBL account through a custodian (who is not a broker) then they must advise their custodian that they have sold as they do for physical securities. However, the securities must be in a CDBL account before they are sold and the broker may wish to check this fact with the custodian before executing the order. On the settlement date of a bough trade the broker will move securities to the account of the buying investors (provided the investor has paid). Investors may leave the securities in their account (ready for sale when they wish to sell or to avoid the need to hold certificates) or they may request the participant to rematerialize the securities.

\subsection{Fees \& Deposits}

CDBL will charge fees to participants, issuers and Direct Account Holders, who are also required to lodge security deposits with CDBL, which are refundable upon termination. CDBL does not charge fees directly to account holders. Participants are charged fees which they may recover from investors holding accounts with them. Prospective Direct Account Holders should contact CDBL for an up to date fees \& deposits schedule.

\section{An Appraisal of the Activities of CDBL}

This section evaluates the activities, development and prospect of CDBL from year 2007 to 2015. In esteem to this analysis various variables i.e. number of shares, listed securities, depository participants (DPS), number of shares settled in CDS, documentation, dematerialization of securities, settlement of securities transaction, net income, total assets, retained earnings, EPS and their growth percentage has been considered to evaluate the escalation of CDBL. This study also measured the trend equations and $\mathrm{r}^{2}$ for the different mentioned variables.

\subsection{Growth of Number of Shares in the CDS}

Number of shares held in the CDS (Table 1) increased by 383,505,144 taking the total from 714.417 million as at 30th June '07 to 1,097.922 million as at 30th June '08. Market value of the shares held in CDS as at 30th June ' 07 amounted to around Tk. 166.08 billion which increased to Tk. 406.35 billion as at 30th June ' 08 registering a gain of around 145\%. From year 2008 to 2009 number of shares held in the CDS increased by $68.87 \%$ which market value of around Tk. 406.35 billion as at 30th June ' 08 increased to Tk. 592.17 billion as at 30th June ' 09 scheduling a gain of around $46 \%$. With the increase in securities held in the depository, share transfers in the depository relating to settlement of stock exchange trades during the year were significantly higher compared to the previous year, furthermore, transactions value up over 65 percent resulting in an upsurge in the income stream. For the duration of year 2010 this number increased by 3,558,695,047 (around 192\%) taking the total from $1,854,028,146$ as at 30th June ' 09 to $5,412,723,193$ as at 30th June ' 10 wherever market value of these shares increased to Tk. 1,395.95 billion as at 30th June ' 10 recording a gain of around $136 \%$. Besides that because of number of shares splits to Tk. 10 per share from Tk. 100 per share number of shares held in the CDS increased to 16,995,251,631 (around 214\%) and 31,828,867,329 (87.28\%) as at 30th June 2011 to 2012 indexing an increase of around 16\% of market value of shares (Tk. 1,624,89 billion) and decreased to Tk.1,354.68 billion as at 30th June 2012 rolling a decline of around 17\% (Tk.1,354.68 billion).

On the other hand Market value of the shares held in CDS as at 30th June 2012 amounted to around Tk. 1,354.68 billion which increased to Tk.1,399.16 billion as at 30th June 2013 registering a gain of over 3\%. Number of shares held in the CDS increased during the year by 7,531,192,268 (around 20\%) taking the total from 36,877.129 million as at 30th June 2013 to 44,408.321 million as at 30th June 2014. Market value of the shares held in CDS as at 30th June 2013 amounted to around Tk. 1,399.16 billion which increased to Tk.1, 577.07 billion as at 30th June 2014 registering a gain around $13 \%$.

Conversely number of shares held in the CDS increased around 15\% during the year by 6,465,981,153 taking the total from 44,408,321,318 as at 30th June 2014 to 50,874,302,471 as at 30th June 2015. Market value of the shares held in CDS as at 30th June 2014 amounted to around Tk. 1,577.07 billion which increased to Tk. $1,776.16$ billion as at 30th June 2015 registering a gain around $13 \%$. 
Table 1. Growth of number of shares in the CDS

\begin{tabular}{lcl}
\hline Year & Number of Shares in the CDS (Millions) & Growth (\%) \\
\hline 2007 & 714.41 & -- \\
2008 & 1097.92 & 53.68 \\
2009 & 1854.02 & 68.87 \\
2010 & 5412.72 & 191.94 \\
2011 & 16995.25 & 213.99 \\
2012 & 31828.86 & 87.28 \\
2013 & 36877 & 15.86 \\
2014 & 44408 & 20.42 \\
2015 & 50874 & 14.56 \\
\hline
\end{tabular}

Source: Author's calculation using the different issues of Annual Report of CDBL

Note. US \$1 = BDT 78 .

\subsection{Growth of Listed Securities in CDS}

Table 2 demonstrated Listed Securities in CDS which increases from year 2007 to year 2015. By griping to this development 32 publicly listed companies came into the CDS during the year taking the total from 118 as at 30th June ' 07 to 150 as on 30th June ' 08 . On the other hand 31 publicly listed companies came into the CDS while 2 companies i.e. Beximco Fisheries Ltd. and Shinepukur Holdings Ltd. went out of the CDS count having merged with BEXIMCO Ltd. during the year taking the total from 150 as at 30th June ' 08 to 179 as at 30th June ' 09 . From year 2009 to year 2010 listed securities showed $25.70 \%$ growth while the trend gradually decreased to $22.22 \%$ to $6.18 \%$ during year 2011 to year 2012.Conversely from year 2013 to 2014 listed securities decreased to $5.48 \%$ to $4.55 \%$ because of listed securities at DSE stood at 315 at the end of the year made up of 263 companies, 41 mutual funds, 8 debentures and 3 corporate bonds excluding 221 Bangladesh Government Treasury Bonds at 30th June 2014.In year 2015 listed securities increased by 7.45\% from the preceding year.

Table 2. Growth of listed securities in CDS

\begin{tabular}{lcl}
\hline Year & Listed Securities in CDS & Growth $(\%)$ \\
\hline 2007 & 118 & -- \\
2008 & 150 & 27.12 \\
2009 & 179 & 19.33 \\
2010 & 225 & 25.70 \\
2011 & 275 & 22.22 \\
2012 & 292 & 6.18 \\
2013 & 308 & 5.48 \\
2014 & 322 & 4.55 \\
2015 & 346 & 7.45 \\
\hline
\end{tabular}

Source: Author's calculation using the different issues of Annual Report of CDBL

Note. US \$1 = BDT 78 .

\subsection{Growth of Depository Participants of CDBL}

The participants of CDBL are called Depository Participant (DP). Table-3 showed that Depository Participants (DP) increased by $28,22,28,28,17,18,13$ and 10 during the year ended $30^{\text {th }}$ June ' 08 to $30^{\text {th }}$ June 2015 . The growth of Depository Participants (DP) increased from year 2007 to 2015 but it is fluctuating every year and at the end $30^{\text {th }}$ June 2015 growth was $2.66 \%$ which was much below of the preceding years.

Table 3. Growth of depository participants of CDBL

\begin{tabular}{ccc}
\hline Year & Depository Participants to CDBL & Growth $(\%)$ \\
\hline 2007 & 222 & -- \\
2008 & 250 & 12.61 \\
2009 & 272 & 8.80 \\
2010 & 300 & 10.29 \\
2011 & 328 & 9.33 \\
2012 & 345 & 5.18 \\
2013 & 363 & 5.22 \\
2014 & 376 & 3.58 \\
2015 & 386 & 2.66 \\
\hline
\end{tabular}

Source: Author's calculation using the different issues of Annual Report of CDBL Note. US \$1 = BDT 78 . 


\subsection{Growth of Documentation of $C D B L$}

Table 4 showed growth of documentation of CDBL. The table imitated that growth of documentation of CDBL fluctuate every year from year 2008 to year 2015. But in year 2008 growth was highest which $61 \%$ is and in year 2012 growth was lowest which $59 \%$.

Table 4. Growth of documentation of CDBL

\begin{tabular}{ccc}
\hline Year & Documentation & Growth $(\%)$ \\
\hline 2007 & 101939 & - \\
2008 & 164320 & 61 \\
2009 & 140000 & -15 \\
2010 & 205000 & 46 \\
2011 & 235000 & 15 \\
2012 & 97500 & -59 \\
2013 & 110000 & 13 \\
2014 & 72,500 & -34 \\
2015 & 56,374 & -22 \\
\hline
\end{tabular}

Source: Author's calculation using the different issues of Annual Report of CDBL

Note. US \$1 = BDT 78 .

\subsection{Growth of Dematerialization of Securities of CDBL}

Table 5 showed growth pattern of dematerialization of securities of CDBL. The table reflected number of dematerialization of securities increasing but at a decreasing trend from year 2008 to 2011. But from year 2012, 2013 and 2015 it is decreased by $70 \%, 50 \%$ and $73 \%$.

Table 5. Growth of dematerialization of securities of CDBL

\begin{tabular}{ccc}
\hline Year & Dematerialization of Securities (Million BDT) & Growth $(\%)$ \\
\hline 2007 & 3.75 & - \\
2008 & 7.90 & 111 \\
2009 & 9.29 & 18 \\
2010 & 17.41 & 87 \\
2011 & 23.22 & 33 \\
2012 & 6.97 & -70 \\
2013 & 3.48 & -50 \\
2014 & 4.21 & 21 \\
2015 & 1.14 & -73 \\
\hline
\end{tabular}

Source: Author's calculation using the different issues of Annual Report of CDBL

Note. US \$1 = BDT 78 .

9.6 Growth of Settlement of Securities Transactions of CDBL

Table 6 illustrated growth of Settlement of Securities Transactions of CDBL. The table reflected that Settlement of Securities Transactions of CDBL increasing at a decreasing trend from year 2008 to 2011. But from year 2012, 2013 and 2015 it is decreased by $54 \%, 35 \%$ and $17 \%$.

Table 6. Growth of settlement of securities transactions of CDBL

\begin{tabular}{ccc}
\hline Year & Settlement of Securities Transactions (Million BDT) & Growth $(\%)$ \\
\hline 2007 & 88.54 & -- \\
2008 & 302.92 & 242 \\
2009 & 508.07 & 68 \\
2010 & 867.11 & 71 \\
2011 & 1241.11 & 43 \\
2012 & 569.85 & -54 \\
2013 & 369.35 & -35 \\
2014 & 469.75 & 27 \\
2015 & 389.82 & -17 \\
\hline
\end{tabular}

Source: Author's calculation using the different issues of Annual Report of CDBL

Note. US \$1 = BDT 78 .

\subsection{Growth of Net Profit of CDBL}

From Table 7 it is reflected that outstanding financial results have been achieved in the year 2008 where net profit is increased by $254.40 \%$ compared to the previous year as a result of growth in income from depository 
operations of around 203\%. From year 2009 to 2011 net profit increased by around 55\%, 59\% and $72 \%$ as a consequence of the favorable market conditions and the tight lid maintained expenditure. However, after 2011 net Profit of CDBL decreased by $20 \%$ in 2012 and it continue falling in year 2013 and year 2015 as the incapability of the company to handle the expenditure. So it is reflected from the table that net profit of CDBL has shown up and down trends during the period of 2007-2015.

Table 7. Net profit of CDBL

\begin{tabular}{ccc}
\hline Year & Net Profit (Million BDT) & Growth $(\%)$ \\
\hline 2007 & 99.55 & \\
2008 & 352.82 & 254.40 \\
2009 & 545.70 & 54.67 \\
2010 & 867.15 & 58.91 \\
2011 & 1492.69 & 72.14 \\
2012 & 1194.08 & -20.00 \\
2013 & 878.47 & -26.43 \\
2014 & 978.59 & 11.40 \\
2015 & 884.74 & -9.59 \\
\hline
\end{tabular}

Source: Author's calculation using the different issues of Annual Report of CDBL.

Note. US $\$ 1=$ BDT 78 .

9.8 Growth of Total Assets of CDBL

Conversely Table 8 exposed total assets of the company which showed an increasing trend from year 2007 to 2010 reflecting well supervision of both current and fixed asset. The growth trend of the assets during 2008, 2009 and 2010 was around $68 \%, 58 \%$ and $67 \%$. The trend was drastically decreased by $72 \%$ during 2011 due to a financial or operational problem of the company. After 2011 total assets increased year after year and the growth rate peak in year 2013 which is $781.46 \%$.

Table 8. Total assets of CDBL

\begin{tabular}{ccc}
\hline Year & Total Assetsm (Million BDT) & Growth $(\%)$ \\
\hline 2007 & 485.29 & - \\
2008 & 812.29 & 67.38 \\
2009 & 1278.41 & 57.38 \\
2010 & 2128.96 & 66.53 \\
2011 & 595.90 & -72.01 \\
2012 & 629.98 & 5.72 \\
2013 & 5553.10 & 781.46 \\
2014 & 6182.47 & 11.33 \\
2015 & 6411.76 & 3.71 \\
\hline
\end{tabular}

Source: Author's calculation using the different issues of Annual Report of CDBL.

Note. US \$1 = BDT 78 .

\subsection{Growth of Earnings Per Share (EPS)}

The growth pattern of EPS has been revealed from Table 9. It is depicted from the table that the growth of EPS showed negative in 2009, 2011, 2012, 2013 and 2014 which was $-22.65 \%,-25.54 \%,-36.01 \%$ and $-10.22 \%$. The EPS of the company uphold ups and down trend through year 2007 to 2012. During year 2008 EPS was dramatically increased by around $256 \%$. Furthermore it declined to Tk. 5.97 from Tk. 9.33 reflecting the effect of the bearish market during the year on the income of the company. The lowest growth observed in 2012 . The growth percentage of EPS showed very dissatisfactory depiction year after year.

Table 9. Earnings per share of CDBL

\begin{tabular}{ccc}
\hline Year & Earnings per share(BDT) & Growth $(\%)$ \\
\hline 2007 & 2.87 & -- \\
2008 & 10.2 & 255.40 \\
2009 & 7.89 & -22.65 \\
2010 & 12.53 & 58.81 \\
2011 & 9.33 & -25.54 \\
2012 & 5.97 & -36.01 \\
2013 & 4.89 & -18.09 \\
2014 & 4.39 & -10.22 \\
2015 & 4.42 & 0.68 \\
\hline
\end{tabular}

Source: Author's calculation using the different issues of Annual Report of CDBL.

Note. US \$1 = BDT 78 . 


\subsection{Growth of Paid-Up-Capital and Retained Earnings}

Table 10 explicated paid -up-capital and retained Earnings of CDBL. Retained earnings used to maintain current operations, or to invest in new ventures. Retained Earnings Growth is the percent increase/decrease of a company's retained net income over time. CDBL retained earnings illustrated an upward sloping trend from year 2007 to 2011 indicated that the growth is accompanied by subsequent increases in sales and profitability. Due to financial recession the trend decreased by around 9\% in year 2012, 90.40\% in year 2013and $2.60 \%$ in year 2015 but consequently increased by $15.46 \%$ in year 2014 .

CDBL paid -up- capital remained constant from year 2007 to 2009 maintained a zero growth rate. Although in year 2010 it was Tk. 690 million which was reached the threshold of Tk. 500 million set by SEC for mandatory share issuance to the public. After that it raised by around 132\% and 25\% during year 2011 and 2012. The company issued 40,000,000 bonus shares in year 2012 which has increased the paid up capital of the company to Tk. 2 billion. After year 2012 paid-up-capital remained constant up to year 2015.

Table 10. Paid-up-capital \& retained earnings of CDBL

\begin{tabular}{ccccc}
\hline Year & Paid-Up-Capital (Million BDT) & Growth $(\%)$ & Retained Earnings (Million BDT) & Growth (\%) \\
\hline 2007 & 346 & -- & 104 & -- \\
2008 & 346 & 0.00 & 422 & 307.18 \\
2009 & 346 & 0.00 & 878 & 108.11 \\
2010 & 690 & 99.42 & 1364 & 55.43 \\
2011 & 1600 & 131.88 & 5807 & 325.59 \\
2012 & 2000 & 25.00 & 5294 & -8.84 \\
2013 & 2000 & 0.00 & 508 & -90.40 \\
2014 & 2000 & 0.00 & 587 & 15.46 \\
2015 & 2000 & $0.00 \%$ & 572 & $-2.60 \%$ \\
\hline
\end{tabular}

Source: Author's calculation using the different issues of Annual Report of CDBL.

Note. US \$1 = BDT 78 .

\subsection{Trend Equation of CDBL}

Table 11 showed the summary of trend equation and $\mathrm{r}^{2}$ of number of shares in the CDS, listed securities in CDS, depository participants to CDBL, dematerialization of securities, settlement of securities transactions of CDBL, net profit, total assets and EPS.

It is observed from the table that number of shares in the CDS trend equation is positive and goodness of fit is higher than 0.50 i.e. 0.60. On the other hand trend equation of listed securities in CDS is positive and goodness of fit is more than 0.50. It is exposed from the table that a trend equation of depository participant to CDBL is positive and goodness of fit is more than 0.50. Dematerialization of securities of CDBL trend equation is not positive and goodness of fit is very low i.e. 0.19. Trend equation of settlement of securities transactions of CDBL is negative and goodness of fit is very low i.e. 0.02. The table also showed that trend equation of net profit of CDBL is positive but goodness of fit of the equation is low i.e. 0.22.Trend equation and $r^{2}$ of total assets of CDBL is positive but Goodness of fit is not in a satisfactory level which is 0.17 and trend equation of EPS is negative where Goodness of fit is 0.42 .

Table 11. Trend equation and $\mathrm{r}^{2}$

\begin{tabular}{lcc}
\hline \multicolumn{1}{c}{ Particulars } & Yc= $\mathrm{a}+\mathrm{bx}$ & $\mathrm{r} 2$ \\
\hline Number of Shares in the CDS & $\mathrm{Yc}=20.45+246.11 \mathrm{x}$ & 0.62 \\
Listed Securities in CDS & $\mathrm{Yc}=20.45+246.11 \mathrm{x}$ & 0.48 \\
Depository Participants to CDBL & $\mathrm{Yc}=14.48+315.78 \mathrm{x}$ & 0.46 \\
Dematerialization of Securities & $\mathrm{Yc}=-1.15+8.6 \mathrm{x}$ & 0.19 \\
Settlement of Securities Transactions & $\mathrm{Yc}=20.45+246.11 \mathrm{x}$ & 0.02 \\
Net Profit & $\mathrm{Yc}=72.4-810.43 \mathrm{x}$ & 0.22 \\
Total Assets & $\mathrm{Yc}=391.58+2675.35 \mathrm{x}$ & 0.17 \\
EPS & $\mathrm{Yc}=20.45+246.11 \mathrm{x}$ & 0.41 \\
\hline
\end{tabular}

\section{Findings and Conclusion}

The establishment of CDBL added value to the stock market of Bangladesh and attracted more investors' especially foreign investors. Before the establishment of CDBL process of transferring and delivering ownership was too lengthy and risky. After implementing automated trading system in DSE \& CSE and introducing central 
depository system, the stock market of Bangladesh became more effective and credible to the investors (Bepari $\&$ Mollik).

The proceedings of CDBL in the coming year appear to be excellent though the stock market may be vulnerable to overheating which invariably leads to a bubble burst at some stage. The increasing number of users of the Company's CDS is most stirring and intensely appreciated. The Company has nonetheless made investments to be technologically well placed with new up-graded scalable systems to handle any extraordinary upsurge in trade volumes at the stock exchanges efficiently and deliver significant improvements in its service to depository participants and issuers.

It has been observed that net income, depository participants, dematerialization of securities, settlement of securities, number of shares, listed securities of CDBL has increased from the previous year during 2007-2015 which indicated that CDBL is able to perform activities efficiently. Every year the company's total assets increased.

Seven trend equations have been tested for different activities of CDBL. Among them the trend value of all activities except EPS, settlement of securities and dematerialization of securities is positive. Square of correlation coefficient $\left(r^{2}\right)$ has also been tested for all trend equations. The $r^{2}$ of depository participants and listed securities in CDS is more than 0.5 which indicates the prospect of CDBL is bright.

The growth percentage of EPS of CDBL was very low and fluctuating. In order to increase activities and income CDBL need to increase income. It has been identified that the growth rate of net income and EPS is not satisfactory. CDBL should try to increase the growth rate.

We are quite optimistic that if the given suggestions of this paper are implemented then CDBL will be able to overcome its present problems and may contribute in the rapid development of the economy of Bangladesh.

\section{References}

Azim, M., Ahmed, E., \& D’Netto, B. (2011). Corporate Social Disclosure in Bangladesh: A Study of the Financial Sector. International Review of Business Research Papers, 7, 37-55.

Chaity, N. S., \& Sharmin, S. (2012). Efficiency Measures of Capital Market: A Case of Dhaka Stock Exchange. International Journal of Business and Management, 7(1).

Islam. K. A. R. (2007). The prospects, possibilities and challenges of Bangladesh capital market. The Financial Express.

Kanan, S. (2008). Market Comparable Approach. Journal of Financial Services Research, 24, 121-148.

Mujeri, M. K., \& Rahman, M. H. (2009). Financing Long Term Investments in Bangladesh: Capital Market Development Issues. Paper provided by esocialsciences.com in its series Working Papers with number id: 2060.

Saha, A. K. (2012). Capital Market in Bangladesh: An Overview. International Journal of Science and Research (IJSR), 1(3).

Sing, S., \& Goyal, S. (2011). Analysis Factor Affecting the decision making of the investors in Depository system. Journal of Banking, Financial Services and Insurance Research, 1, 13-38.

Solaiman, S. M. (2006). Recent Reforms and the Development of the Securities Market in Bangladesh. Journal of Asian and African Studies, 41(3). https://doi.org/10.1177/0021909606063878

\section{Copyrights}

Copyright for this article is retained by the author(s), with first publication rights granted to the journal.

This is an open-access article distributed under the terms and conditions of the Creative Commons Attribution license (http://creativecommons.org/licenses/by/4.0/). 